\title{
A Comparison Between Serological and Biological Assays in Detecting Grapevine Leafroll Associated Viruses
}

\author{
Adib Rowhani, Department of Plant Pathology, Jerry K. Uyemoto, USDA-ARS, and Deborah A. Golino, De- \\ partment of Plant Pathology, University of California, Davis 95616
}

\begin{abstract}
Rowhani, A., Uyemoto, J. K., and Golino, D. A. 1997. A comparison between serological and biological assays in detecting grapevine leafroll associated viruses. Plant Dis. 81:799-801.

The efficacy of the serological procedure enzyme-linked immunosorbent assay (ELISA) for detecting grapevine leafroll associated viruses (GLRaV types -1, -2, -3, and -4) was compared with indexing on Vitis vinifera L. cv. Cabernet Franc. Results of the biological assays confirmed the infectious nature of all grapevine sources testing positive by ELISA for GLRaV-1 ( 9 sources), GLRaV-2 (14 sources), and GLRaV-4 (14 sources), and the noninfectious nature of ELISA-negative grapevines ( 75 sources). However, among 57 sources testing positive by ELISA for GLRaV-3, or 24 sources with multiple infections, 8 and 1 sources, respectively, were negative by Cabernet Franc assays. Serological assays were repeated on all graft-inoculated indicators and only symptomatic ones reacted positively. Also, the 8 original GLRaV-3 sources that had tested positive by ELISA and negative by bioassay were found positive using immunocapture/reverse transcription-polymerase chain reaction (IC/RT-PCR). The single multiple-infected source was not available for retesting. The distribution of GLRaV in infected grapevines was tested by assaying 20 to 40 samples per source of 36 plants infected with GLRaV-1, -2, -3, or -4 . The incidence of GLRaV-positive canes as determined by ELISA ranged from 0 to $100 \%$, suggesting that GLRaV can be unevenly distributed in chronically infected grapevines.
\end{abstract}

Grapevine leafroll disease was first identified in California in 1958 (11) and reported to affect fruit coloration, maturation, and yield in the red table grape Emperor, Vitis vinifera L. Although crop loss varied widely, a $20 \%$ yield reduction was common for diseased grapevines (10), along with reduced vegetative growth. In mixed infections more severe symptoms occur, including vine death (Golino, unpublished). Disease symptoms are dependent upon the virus isolate, grape variety, and/or environmental conditions, and because of this many infected vines may be asymptomatic, making visual diagnosis difficult.

Grapevine leafroll disease is apparently caused by several antigenically distinct closteroviruses (referred to hereafter as grapevine leafroll-associated closterovirus, GLRaV; 3,5,6,8,12-14,16,21,22). Their control is dependent upon the effectiveness of clean stock programs. Strict quarantine measures exist in many countries, including the United States, to control the importation of diseased materials. In addition, both virus research and the importation, certification, and registration programs for grapevines have depended largely on bio-

Corresponding author: A. Rowhani

E-mail: akrowhani@ucdavis.edu

Fax: (916) 752-2132

Accepted for publication 9 April 1997.

Publication no. D-1997-0519-05R

(C) 1997 The American Phytopathological Society logical indexing for leafroll disease using budchips grafted onto $V$. vinifera $\mathrm{cv}$. Cabernet Franc, a sensitive indicator for leafroll disease agents. Grafted indicator plants are grown in the field and observed for 2 to 3 years before readings are completed.

With the recent availability of certain specific antisera, it appears that enzymelinked immunosorbent assay (ELISA) could substitute for or supplement the biological assays in certification and registration programs. With ELISA, many more samples can be tested rapidly. However, some problems must be resolved. For example, previous surveys of older vineyards with mixed virus infections have produced inconsistent results with biological and serological assays $(9,18)$; some grapevines that tested positive by biological index were negative by ELISA. Since antisera are not yet available for all known GLRaV types, these anomalies were not totally unexpected. Conversely, some grapevines have tested positive only by ELISA.

In this paper, a large grapevine collection containing several commercially important wine varieties and clones was extensively examined by ELISA. These same plants were also indexed biologically, and the results were compared to those from ELISA. Also, results of a study measuring distribution of GLRaV in chronically infected grapevines are reported.

\section{MATERIALS AND METHODS}

Grapevine source. ELISA testing was used to establish the group of vines for study. Most of the vines were in the collections of Foundation Plant Materials Service, University of California, Davis. The majority were located in a 25 -year-old planting known as the old Foundation vineyard (18). The vines in this vineyard collection had been previously indexed on the Cabernet Franc indicator. Thus, included in this experimental set were vines known to be chronically infected, recently infected vines, and healthy vines. Many different varieties were included in the study. An initial ELISA test of the old foundation vineyard was performed and several of the positive and negative sources (as evaluated by ELISA) were regrafted onto Cabernet Franc indicator.

ELISA. Polyclonal antisera of GLRaV-1 and GLRaV-3 were produced in our laboratory. Those of GLRaV-2 and GLRaV-4 were a gift from Dr. Dennis Gonsalves $(2,13)$. The double antibody sandwich method (4) was used for GLRaV-1 detection. The wells were precoated with polyclonal antibody and viral antigens detected with a probe solution of GLRaV-1-specific monoclonal antibody conjugated to alkaline phosphatase enzyme (Bioreba Inc. West Bend, IN). For detection of GLRaV2, GLRaV-3, and GLRaV-4, the F(ab') ELISA procedure as previously described (17) was used with minor modifications, which included the cross-absorption of purified IgG and alkaline phosphataseconjugated protein $\mathrm{A}$ in $\mathrm{a}$ solution containing $10 \%(\mathrm{vol} / \mathrm{vol})$ healthy grape leaf tissue homogenate, prepared by homogenizing $1 \mathrm{~g}$ leaf tissue in $10 \mathrm{ml}$ PBS extraction buffer (PBS containing 0.05\% [vol/vol] Tween 20, 2\% [wt/vol] PVP 40, and $0.2 \%$ [wt/vol] BSA). This was done to reduce the nonspecific background.

Candidate vines were tested by ELISA for GLRaV prior to biological indexing on Cabernet Franc. Samples were made up of six to eight randomly selected, basal positioned mature-leaf petioles or canes per grapevine. Leaf petioles or bark scrapings were homogenized in extraction buffer (0.05 M carbonate buffer, $\mathrm{pH} 9.6$ containing 2\% [wt/vol] PVP 40, 0.2\% [wt/vol] $\mathrm{BSA}$, and $0.05 \%$ [vol/vol] Tween 20$)$ at a rate of $1 \mathrm{~g}$ tissue per $10 \mathrm{ml}$ buffer. The absorbance of each well at $405 \mathrm{~nm}$ was measured and extracts were considered negative if the optical density values were less than two times the values of healthy controls; questionable if between two and four times those of controls; and positive when over four times those of controls. 
Biological indexing. Dormant canes were collected only from grapevines previously tested by ELISA. During April and May a total of 6 budchips from each collection were grafted onto 3 rooted cuttings of Cabernet Franc, using 2 grafts per indicator. Grafted plants were held in the greenhouse for 1 month, read for budchip viability, and briefly acclimated in a lathhouse before being transplanted in the field. The grafted plants were cultivated there for 2 growing seasons and read for symptoms in October to November of the second year. On Cabernet Franc, diseased leaf symptoms consisted of interveinal red coloration with the principle veins remaining green, accompanied by a downward rolling of the leaf margins. Concomitant with visual inspection, all grafted indicators were tested by ELISA.

Distribution of GLRaV in grapevines. The relative titers throughout the canopies of 36 grapevines infected with GLRaV-1 (3 sources), GLRaV-2 (7 sources), GLRaV-3 (17 sources), and GLRaV-4 (9 sources) were measured by ELISA. The sampling procedure consisted of collecting tissues, a minimum of 20 to a maximum of 40 petioles or canes per tested grapevine. Sample size was dependent upon vigor of the grapevine.

Polymerase chain reaction. The immunocapture/reverse transcription-polymerase chain reaction (IC/RT-PCR) assay was performed as described previously (19) and used to retest 8 sources testing positive for GLRaV-3 by ELISA and negative by Cabernet Franc indicator. The primers were specific for the coat protein gene of GLRaV-3 (15).

\section{RESULTS}

A total of 221 grapevines were compared by both assay procedures. ELISA results indicated that 9 vines were positive using reagents specific for GLRaV-1; however, these same vines were also positive with the GLRaV-2 reagent (Note: the latter source was recently determined to contain antibodies to both GLRaV-1 and GLRaV-2 [1]). In addition, 57 grapevines were positive for only GLRaV-3; 14 each for only GLRaV-2 (these sources were negative with the GLRaV-1 reagents) or GLRaV-4; and 24 were multiply infected (Table 1). Another 28 sources produced questionable readings, and 75 more were negative with our panel of ELISA reagents.

With biological indexing, at least one budchip and often both per indicator plant had callused when examined 1 month postinoculation. Furthermore, all vines testing positive by ELISA for GLRaV-1, GLRaV2, and GLRaV-4 were symptomatic for leafroll disease. However, among all grapevines positive for GLRaV-3, those with multiple infection, and those with questionable results by ELISA, only 49 of 57,23 of 24 , and 3 of 28 , respectively, were positive by biological indexing. When all graft-inoculated indicator plants were tested by ELISA, only the symptomatic ones were positive. The remainder, comprising asymptomatic indicators or those grafted with the ELISA-negative sources, were negative.

Our failure to detect leafroll in 8 of the ELISA GLRaV-3 positives by bioassay suggested that these may represent ELISA false-positives. However, assays by IC/RT-PCR of the original sources also were positive for GLRaV-3, supporting the idea that use of an occasional healthy budchip from infected grapevines, or failure of an infected budchip to survive, contributed to the negative results of the bioassay.
Similarly, results of the distribution of GLRaVs from 36 selected sources showed that GLRaV was not uniformly distributed throughout the canopy (Table 2). GLRaV was detected in over $75 \%$ of the samples taken from 20 sources, while in 9 other sources the detection ranged from 2.5 to $75 \% ; 7$ other sources of GLRaV-3 tested negative in this experiment. Eleven vines from this experiment were included in earlier biological assays; three tested negative on the Cabernet Franc indicator. These three vines were among those showing $100 \%$ infection with GLRaV-3.

\section{DISCUSSION}

Although natural spread of GLRaV is now being reported $(6,7,20)$, the disease agent is most efficiently disseminated by propagating from infected sources. The use of certified, virus-tested grapevines for propagation and the establishment of vineyards is the best insurance against introducing the disease into new vineyard sites. ELISA is specific, sensitive, and tests are completed in 1 or 2 days. This compares favorably to the more lengthy incubation period needed for biological indexing on Cabernet Franc indicator. Our results also showed that GLRaV-seroassays could be used to rapidly detect and identify the closteroviruses associated with leafroll disease, and to screen candidate grapevines selected for purposes of propagation.

Even so, inconsistencies occurred between the assay procedures for GLRaV-3; e.g., 8 sources were positive by ELISA, but tested negative by biological indexing. Retests of these same sources by IC/RTPCR confirmed the ELISA results, suggesting that perhaps GLRaV-3 was not uniformly distributed in these vines. Negative test results from known diseased

Table 1. Comparison of ELISA and biological index on Cabernet Franc (C. Franc) of grapevine sources infected with different types of grapevine leafroll associated viruses (GLRaV)

\begin{tabular}{|c|c|c|c|c|c|c|}
\hline \multicolumn{3}{|c|}{ ELISA results on source plants } & \multicolumn{2}{|c|}{ Indexing on C. Franc } & \multicolumn{2}{|c|}{ ELISA results on C. Franc indicators } \\
\hline Results & Virus & No. & No. neg & No. pos & No. neg & No. pos \\
\hline \multirow[t]{5}{*}{$\overline{\text { Pos }}$} & GLRaV-1 & 9 & 0 & 9 & 0 & 9 \\
\hline & GLRaV-2 & 14 & 0 & 14 & 0 & 14 \\
\hline & GLRaV-3 & 57 & 8 & 49 & 8 & 49 \\
\hline & GLRaV-4 & 14 & 0 & 14 & 0 & 14 \\
\hline & Mult. Inf.a & 24 & 1 & 23 & 1 & 23 \\
\hline Ques $^{\mathrm{b}}$ & & 28 & 25 & 3 & 25 & 3 \\
\hline $\mathrm{Neg}$ & & 75 & 75 & 0 & 75 & 0 \\
\hline
\end{tabular}

a These sources were multiply infected with different GLRaVs.

${ }^{\mathrm{b}}$ Tissue extracts of these sources produced ELISA values in between those considered healthy and virus-positive.

Table 2. Distribution of grapevine leafroll-associated viruses (GLRaV) in grapevines. Twenty to 40 subsamples were collected per source and tested by ELISA

No. of sources and percentage of samples positive by ELISA

\begin{tabular}{lcccccc}
\cline { 2 - 6 } Types of GLRaV & No. vines tested & $\mathbf{7 6 - 1 0 0 \%}$ & $\mathbf{5 1 - 7 5 \%}$ & $\mathbf{2 6 - 5 0 \%}$ & $\mathbf{2 . 5}-\mathbf{2 5 \%}$ & 0 \\
\hline 1 & 3 & 3 & 0 & 0 & 2 & 0 \\
2 & 7 & 4 & 1 & 0 & 3 & 0 \\
3 & 17 & 7 & 0 & 1 & 1 & 0 \\
4 & 9 & 6 & 1 & 1 & 6 & 7 \\
\hline
\end{tabular}


sources confirmed the limitations of current sampling strategies. To partially circumvent this issue, more samples should be collected, with additional number of budchips grafted to woody indicators, or the number of tissue extraction for serology should be increased. Overall, our results illustrated the efficacy of ELISA compared to graft-indexing in detecting GLRaV. In our opinion, ELISA is the method of choice to rapidly screen grapevine sources intended for propagation.

The antiserum source labeled as GLRaV-2 (produced in D. Gonsalves's laboratory) was recently reported to contain antibodies to GLRaV-1 and GLRaV-2 (1). Unlike GLRaV-1, with a coat protein $\mathrm{M}_{\mathrm{r}}$ of $36 \mathrm{kDa}$, the GLRaV-2 designation is currently restricted to a closterovirus with a coat protein $\mathrm{M}_{\mathrm{r}}$ of $26 \mathrm{kDa}$ ( 2 and 22). In our study, 9 sources of GLRaV-1 also reacted with the GLRaV-2 antiserum, suggesting a potential for mixed virus infections. The 14 sources reacting with GLRaV-2 antiserum were negative when tested in GLRaV-1 ELISA.

Eleven vines from the virus distribution experiment (Table 2) were also tested by bioassay. From these vines, three were categorized in the 76 to $100 \%$ infection range and were positive by PCR, but tested negative by graft indexing on Cabernet Franc. This discrepancy also indicates that GLRaV was not uniformly distributed in these vines. However, before any laboratory test can be substituted for the Cabernet Franc indexing test, it will need to detect the entire range of viruses that cause grapevine leafroll disease. Moreover, additional research is needed to determine the most efficient sampling strategy of individual vine sources because of uneven virus distribution in the vines.

Our studies have demonstrated that there is a high correlation between the results of ELISA tests for GLRaV-1 to -4 and the results of biological indexing on Cabernet Franc. However, the strengths and weaknesses of each test were revealed by our studies. Our recommendation for quarantine and clean stock programs would be that both tests should be included in any critical testing scheme. Biological indexing is still needed for the establishment of foundation stocks or to clear selections through quarantine. Wood samples for this test need to be representative of the entire vine canopy. ELISA is a valuable test for both early screening and subsequent testing to verify the continued health status of vines in registration and certification programs.

\section{ACKNOWLEDGMENTS}

This work was supported by the California Fruit Tree, Nut Tree, and Grapevine Improvement Advisory Board, and by the American Vineyard Foundation. We thank L. Jia and M. Cunningham for their technical assistance.

\section{LITERATURE CITED}

1. Boscia, D., Greif, P., Martelli, G. P., Walter, B., and Gonsalves, D. 1995. Nomenclature of grapevine leafroll associated putative closteroviruses. Vitis 34:171-175.

2. Boscia, D., Hu, J. S., Golino, D. A., and Gonsalves, D. Characterization of grape leafroll associated closterovirus (GLRaV) serotype II and comparison with GLRaV serotype III. (Abstr.) Phytopathology 80:117.

3. Castellano, M. A., Martelli, G. P., and Savino, V. 1983. Virus-like particles and ultrastructural modifications in the phloem of leafroll affected grapevines. Vitis 22:23-29.

4. Clark, M. F., and Adams, A. N. 1977. Characteristics of the microplate method of enzyme-linked immmunosorbent assay for the detection of plant viruses. J. Gen. Virol. 34:475-483.

5. Conti, M., and Milne, R. G. 1985. Closterovirus associated with leafroll and stem pitting in grapevines. Phytopathol. Mediterr. 24:110113.

6. Engelbrecht, D. J., and Kasdorf, G. G. F. 1985. Association of a closterovirus with grapevines indexing positive for grapevine leafroll disease and evidence for its natural spread in grapevine. Phytopathol. Mediterr. 24:101-105.

7. Engelbrecht, D. J., and Kasdorf, G. G. F. 1990. Transmission of grapevine leafroll disease and associated closteroviruses by the vine mealybug, Planococcus ficus. Phytophylactica 22:341-346.

8. Faoro, F., Tornaghi, R., Fortusini, A., and Bell, G. 1981. Association of a possible closterovirus with grapevine leafroll in Northern Italy. Rev. Pathol. Veg. Entomol. Agric. Fr. 17:183-189.

9. Forsline, P. L., Hoch, J., Lamboy, W. F., Hu, J. S., McFerson, J. R., Golino, D. A., and Gonsalves, D. 1996. Comparative effectiveness of symptomatology and ELISA for detecting two isolates of grapevine leafroll on graft-inocu- lated Cabernet Franc. Am. J. Enol. Vitic. 47:239-243.

10. Goheen, A. C. 1988. Diseases caused by viruses and virus-like agents. Pages 47-54 in: Compendium of Grape Diseases. R. C. Pearson and A. C. Goheen, eds. American Phytopathological Society, St. Paul, MN.

11. Goheen, A. C., Herman, F. N., and Weinberger, J. H. 1958. Leafroll (white Emperor disease) of grapes in California. Phytopathology 48:51-54.

12. Gugerli, P., Brugger, J. J., and Bovey, R. 1984. L'enroulement de la vigen: mise en evidence de particules virales et developpement d'une methode immuno-enyzmatique pour le diagnostic rapide. Rev. Suisse Vitic. Arboric. Hortic. 16:299-304.

13. Hu, J. S., Gonsalves, D., and Teliz, D. 1990. Characterization of closterovirus-like particles associated with grapevine leafroll disease. J. Phytopathol. 128:1-14.

14. Milne, R. G., Conti, M., Lesemann, D. E., Stellmach, G., Tanne, E., and Cohn, J. 1984. Closterovirus-like particles of two types associated with diseased grapevines. Phytopathol Z. 110:360-368.

15. Minafra, A., and Hadidi, A. 1994. Sensitive detection of grapevine virus A, B, or leafroll associated III from viruliferous mealybugs and infected tissue by cDNA amplification. J. Virol. Methods 47:175-188.

16. Namba, S., Yamashita, S., Doi, Y., Yora, Y., and Yano, R. 1979. Grapevine leafroll virus, a possible member of closteroviruses. Ann. Phytopathol. Soc. Jpn. 45:497-502.

17. Rowhani, A. 1992. Use of $F\left(a^{\prime}\right) 2$ antibody fragment in ELISA for detection of grapevine viruses. Am. J. Enol. Vitic. 43:38-40.

18. Rowhani, A. and Golino, D. 1995. ELISA test leads to new information about leafroll disease in certified grapes. Calif. Agric. 49:2629.

19. Rowhani, A., Maningas, M. A., Lile, L. S., Daubert, S. D., and Golino, D. A. 1995. Development of a detection system for viruses of woody plants based on PCR analysis of immobilized virions. Phytopathology 85:347352.

20. Tanne, E., Ben-Doy, Y., and Raccah, B. 1989. Transmission of closterovirus-like particles by mealybugs (Pseudococcidea) in Israel. Phytoparasitica 17:63-64.

21. Zee, F., Gonsalves, D., Goheen, A., Kim, K. S., Pool, R., and Lee, R. F. 1987. Cytopathology of leafroll-diseased grapevines and the purification and serology of associated closterovirus-like particles. Phytopathology 77:1427-1434.

22. Zimmermann, D., Bass, P., Legin, R., and Walter, B. 1990. Characterization and serological detection of four closterovirus-like particles associated with leafroll disease on grapevine. J. Phytopathol. 130:205-218. 